DOI: $10.19195 / 0524-4544.328 .9$

\author{
ANDRZEJ PASEK \\ ORCID: 0000-0001-9468-5204 \\ Uniwersytet Wrocławski \\ andrzej.pasek@uwr.edu.pl
}

\title{
Ewolucja zasady instancyjności w polskim kodeksie postępowania karnego z 1928 roku
}

W momencie odzyskania niepodległości na ziemiach polskich obowiązywały systemy prawne państw zaborczych. Zostały one potraktowane jako dzielnicowe prawo polskie, stosowane na zasadzie ciągłości aż do wypracowania i uchwalenia rodzimych aktów prawnych. W zakresie prawa karnego procesowego były to: rosyjska ustawa postępowania karnego z 20 listopada 1864 roku wraz z przepisami przechodnimi z 1917 roku, austriacka ustawa postępowania karnego z 23 maja 1873 roku oraz niemiecka ustawa postępowania karnego z 1 lutego 1877 roku¹. Na podstawie rozporządzenia Rady Ministrów z 14 października 1922 roku moc obowiązującą austriackiej ustawy postępowania karnego rozszerzono na obszar Spiszu i Orawy ${ }^{2}$. Ponadto do momentu wejścia w życie rozporządzenia obowiązywał na tym terenie węgierski kodeks postępowania karnego z 4 grudnia 1896 $\mathrm{roku}^{3}$.

Utrzymanie w mocy unormowań pozaborowych doprowadziło do ukształtowania się trzech głównych stanowisk w sprawie dalszego rozwoju prawa, spośród których zdecydowanie zwyciężyła idea stworzenia jednolitego i oryginalnego ustawodawstwa polskiego, stopniowo zastępującego obce prawo z czasu zabo-

1 Art. $1 \S 1$ pkt 1-3 rozporządzenia Prezydenta Rzeczypospolitej z dnia 19 marca 1928 roku Przepisy wprowadzające kodeks postępowania karnego (Dz.U. z 1928 r. Nr 33, poz. 314).

2 Rozporządzenie Rady Ministrów z dnia 14 września 1922 roku w przedmiocie organizacji sądownictwa na Spiszu i Orawie i rozciągnięcia na ten obszar mocy obowiązującej niektórych ustaw i rozporządzeń (Dz.U. z 1922 r. Nr 90, poz. 833).

3 Historia państwa i prawa Polski 1918-1939, red. F. Ryszka, cz. 2, Warszawa 1968, s. 28. 
rów ${ }^{4}$. W ramach realizacji tej koncepcji Sejm Ustawodawczy uchwalił ustawę z 3 czerwca 1919 roku $^{5}$ o komisji kodyfikacyjnej6 ${ }^{6}$. Do zadań powołanego na podstawie tej ustawy organu należało również przygotowanie projektu nowego kodeksu postępowania karnego (k.p.k.).

Pierwsze propozycje w sprawie organizacji pracy nad projektem kodeksu sformułowano tuż po ukonstytuowaniu się Wydziału Karnego Komisji Kodyfikacyjnej 12 listopada 1919 roku. Już na tym pierwszym posiedzeniu Wacław Makowski zaproponował podział referatów także z zakresu procedury karnej, a jego stanowisko poparli Aleksander Mogilnicki i Edmund Krzymuski ${ }^{7}$. Jednocześnie uchwalono, żeby „,na razie ani sekcji procedury karnej, ani żadnych innych sekcji w Wydziale Karnym nie tworzyć, a obrady nad zasadami przewodnimi prawa karnego, tak materialnego, jak i formalnego, odbywać w pełnym komplecie Wydziału" . W nawiązaniu do tych ustaleń na drugim posiedzeniu Wydziału Karnego 13 listopada 1919 roku Walenty Miklaszewski zobowiązał się do opracowania referatu w przedmiocie zasad przewodnich procesu karnego, podczas gdy przygotowania koreferatu w tym zakresie podjął się Henryk Ettinger ${ }^{9}$.

Należy także wskazać, że w trakcie pierwszych obrad Zebrania Ogólnego Komisji Kodyfikacyjnej w dniach 11-13 listopada 1919 roku wielu jej członków do najpilniejszych spraw zaliczyło opracowanie projektu ustawy o ustroju sądownictwa. W nawiązaniu do tego postulatu Sekcja Postępowania Cywilnego poleciła Kamilowi Stefce opracowanie zasad ustroju sądownictwa. Referat Stefki stanowił podstawę obrad Sekcji, rozpoczętych 12 kwietnia 1920 roku. Ich rezultatem było uchwalenie wytycznych, które zostały przedłożone Zebraniu Ogólnemu w celu podjęcia stosownych uchwał wiążących w toku dalszej pracy. Równolegle nad zasadami ustroju sądów obradował na posiedzeniach w dniach 11-15 maja 1920 roku Wydział Karny, który swoje wnioski także przedstawił Zebraniu Ogólnemu

4 Odrzucone zostały: 1. utrzymanie partykularyzmu prawnego i poprzestanie na unifikacji jedynie części systemu niezbędnego do funkcjonowania państwa; 2. ujednolicenie systemu prawnego drogą recepcji jednego z obowiązujących na terenie Polski kompleksów norm — Z. Radwański, Ksztaltowanie sie polskiego systemu prawnego w pierwszych latach II Rzeczypospolitej, „Czasopismo Prawno-Historyczne" (dalej: CPH) 21, 1969, nr 1, s. 33.

5 Dziennik Praw Państwa Polskiego z 1919 r. Nr 44, poz. 315.

${ }^{6}$ O genezie, charakterze prawnym, strukturze i organizacji Komisji zob. Z. Radwański, op. cit., s. 31-44; S. Grodziski, Komisja Kodyfikacyjna Rzeczypospolitej Polskiej, CPH 33, 1981, nr 1, s. 47-63; A. Lityński, Wydziat karny Komisji Kodyfikacyjnej II Rzeczypospolitej. Dzieje prac nad częścia ogólna kodeksu karnego, Katowice 1991, s. 11-50; M. Mohyluk, Porzadkowanie prawa w II Rzeczypospolitej: Komisja Kodyfikacyjna i Rada Prawnicza, CPH 51, 1999, nr 1-2, s. 285-299; L. Górnicki, Prawo cywilne w pracach Komisji Kodyfikacyjnej Rzeczypospolitej Polskiej w latach 1919-1939, Wrocław 2000, s. 12-115; A. Pasek, Z organizacyjnych zagadnień kodyfikacji prawa karnego w Drugiej Rzeczypospolitej, „Prawo” 288, 2004, s. 357-378; S. Płaza, Kodyfikacja prawa w Polsce międzywojennej, CPH 57, 2005, nr 1, s. 219-221.

7 Protokót I posiedzenia Wydziału Karnego, [w:] Komisja Kodyfikacyjna Rzeczypospolitej Polskiej (dalej: KK RP), Wydział Karny. Prawo Materialne, t. 1, z. 1, Warszawa 1921, s. 3.

8 Ibidem, s. 5.

9 Protokót II posiedzenia Wydziału Karnego, [w:] KK RP, op. cit., s. 15.

Prawo 328, 2019

(C) for this edition by CNS 
Komisji Kodyfikacyjnej ${ }^{10}$. Na podstawie tych materiałów Zgromadzenie Ogólne, po dyskusji w dniach 17-21 maja 1920 roku, ustaliło zasady ustroju sądownictwa z podziałem na cywilne i karne ${ }^{11}$.

W przedmiocie ustroju sądownictwa karnego uchwalono między innymi następujące zasady:

1. sądy należy tworzyć wspólnie zarówno dla spraw cywilnych, jak i karnych;

2. tworzenie z łona samorządu osobnych sądów gminnych w celu rozpoznania drobnych spraw karnych jest niepożądane;

3. należy utworzyć sądy przysięgłych i powierzyć im rozpoznanie:

a) wszystkich spraw politycznych,

b) przestępstw zagrożonych najcięższymi karami, nie powierzać zaś sądom przysięgłych spraw prasowych, o ile nie należą do jednej z powyższych kategorii;

4. ustrój sądownictwa karnego należy oprzeć na zasadzie dwóch instancji, z jednym nad nimi Sądem Najwyższym, orzekającym tylko w zakresie zarzutów obrazy ustawy:

a) sądy pierwszej instancji są dwojakiego typu: jedne dla spraw mniejszej wagi, inne dla spraw ważniejszych,

b) sądami pierwszej instancji dla spraw mniejszej wagi są sądy powiatowe i miejskie orzekające w składzie jednoosobowym,

c) sądami pierwszej instancji dla spraw ważniejszych są sądy okręgowe orzekające w składzie trzech sędziów,

d) drugą instancją dla sądów powiatowych i miejskich są sądy okręgowe,

e) drugą instancją dla sądów okręgowych (w sprawach bez udziału przysięgłych) są sądy apelacyjne, których zakres zadań określi ustawa postępowania sądowego,

f) Sąd Najwyższy jest wspólną dla sądów drugiej instancji obu typów instancją kasacyjną — zakres jego zadań określi ustawa postępowania sądowego ${ }^{12}$.

W pierwszym roku działalności Wydział Karny nie wykazał istotnej aktywności w zakresie prawa proceduralnego ${ }^{13}$. Sytuacja się zmieniła, gdy 16 lipca 1920 roku utworzono Sekcję Postępowania Karnego ${ }^{14}$. Przystąpiła ona niezwłocznie do opracowania zasad przyszłego projektu kodeksu postępowania karnego, uwzględniając także stanowisko Zgromadzenia Ogólnego Komisji Kodyfikacyjnej ustalone w dniach 17-21 maja 1920 roku. Sekcja Postępowania Karnego podjęła na posiedzeniach w październiku i listopadzie 1920 roku oraz w maju i czerwcu 1921 roku

10 KK RP, Podkomisja ustroju sądownictwa, t. 1, Lwów 1925, s. 3.

11 Ibidem, s. 3, 8.

12 Ibidem, s. 11-12.

13 J. Koredczuk, Wplyw nurtu socjologicznego na ksztatt polskiego prawa karnego procesowego w okresie międzywojennym, Wrocław 2007, s. 82.

14 Komisja Kodyfikacyjna Rzeczypospolitej Polskiej, Dział Ogólny, t. 1, z. 3, Warszawa 1921, s. 99. 
liczne uchwały, opierając się na kwestionariuszu W. Miklaszewskiego, stanowiących podstawę do pracy nad artykułowanym projektem kodeksu ${ }^{15}$.

Na posiedzeniu 9 maja 1921 roku Sekcja wybrała podkomisję do opracowania pierworysu projektu ustawy, w której skład weszli: Edmund Krzymuski, Aleksander Mogilnicki i Zygmunt Rymowicz ${ }^{16}$. Podkomisja 26 października 1923 roku przedłożyła Sekcji projekt artykułowany, który został rozesłany wszystkim członkom wydziału w celu złożenia ewentualnych uwag do 1 grudnia 1923 roku. Sekcja Postępowania Karnego analizowała projekt podkomisji na posiedzeniach w grudniu 1923 roku oraz w styczniu-maju 1924 roku. Przyjęła go w całości 21 maja 1924 roku, powierzając A. Mogilnickiemu opracowanie projektu do druku na podstawie jej uchwał oraz przeprowadzenie zmiany numeracji artykułów i sporządzenie uzasadnienia ${ }^{17}$.

Projekt przyjęty przez Sekcję w drugim czytaniu wydrukowano i rozesłano do zaopiniowania wszystkim członkom Komisji Kodyfikacyjnej oraz sądom, uniwersytetom, towarzystwom prawniczym, a także wybitnym prawnikom, zaznaczając termin do złożenia uwag — do 1 maja 1925 roku. Zostały one rozpatrzone przez podkomisję redakcyjną w kwietniu i czerwcu 1925 roku oraz w styczniu 1926 roku. Projekt zmian zaproponowanych przez podkomisję Sekcja rozpatrzyła w lutym 1926 roku. Następnie 25 lutego 1926 roku Sekcja przyjęła projekt w trzecim czytaniu i poleciła głównemu referentowi A. Mogilnickiemu zestawienie nowego układu artykułów według podjętych uchwał i wprowadzenie nowej numeracji. Sekretarz generalny Komisji Kodyfikacyjnej Emil Stanisław Rappaport 19 maja 1926 roku przedłożył projekt ministrowi sprawiedliwości ${ }^{18}$.

Powołana przez ministra trzyosobowa komisja (w składzie A. Mogilnicki, W. Makowski, S. Śliwiński, przy udziale delegata ministerstwa sprawiedliwości prokuratora S. Kuczyńskiego) zakończyła pracę nad projektem wiosną 1927 roku. Opracowany przez nią projekt kodeksu postępowania karnego został ponownie przedłożony ministerstwu sprawiedliwości, które po wprowadzeniu pewnych zmian doprowadziło do jego wejścia w życie w trybie rozporządzenia Prezydenta Rzeczypospolitej datowanego na 19 marca 1928 roku $^{19}$, które uprawomocniło się 1 lipca 1929 roku$^{20}$.

15 Projekt ustawy postępowania karnego, przyjęty w II czytaniu przez Sekcję Postepowania Karnego Komisji Kodyfikacyjnej Rzeczypospolitej Polskiej, Warszawa 1924 (odbitka z „Gazety Administracji i Policji Państwowej"), s. 3.

16 Projekt ustawy postępowania karnego, przyjęty przez Komisję Kodyfikacyjna Rzeczypospolitej Polskiej w dniu 26 kwietnia 1926 r. z uzasadnieniem i tablica porównawcza, [w:] KK RP, Sekcja Postępowania Karnego, t. 1, z. 1, Lwów 1926, s. 6.

17 Projekt ustawy postepowania karnego, przyjęty w II czytaniu..., s. 3-4.

18 Projekt ustawy postęowania karnego, przyjęty przez Komisję Kodyfikacyjna Rzeczypospolitej Polskiej..., s. 8-10.

19 Rozporządzenie Prezydenta Rzeczypospolitej z dnia 19 marca 1928 roku Kodeks postępowania karnego (Dz.U. z 1928 r. Nr 33, poz. 313 z późn. zm.; dalej: k.p.k. z 1928 r., kodeks z 1928 r.).

20 Historia państwa i prawa..., s. 109. 
Polski kodeks postępowania karnego z 1928 roku charakteryzował się rozbudowaną instancyjnością, będącą ważnym elementem gwarancji procesowych.

Kodeks zawierał przepisy szczególne regulujące postępowanie przed sądem przysięgłych. Stosowano je jednak tylko na terenie byłego zaboru austriackiego. Na obszarach, na których obowiązywały niemiecki kodeks karny z 1871 roku oraz rosyjski kodeks karny z 1903 roku, miały one wejść w życie na podstawie ustawy szczególnej zawierającej katalog ,przestępstw politycznych” podlegających jurysdykcji sądów przysięgłych. Do wydania tego rodzaju aktu prawnego nigdy jednak nie doszło. Na podstawie art. 27 rozporządzenia Prezydenta Rzeczypospolitej z dnia 6 lutego 1928 roku Prawo o ustroju sądów powszechnych ${ }^{21}$ działalność sądów przysięgłych mogła być zawieszona co do wszystkich przekazanych im przestępstw lub pewnych ich rodzajów na całym obszarze państwa lub w pewnych jego okręgach, jeżeli było to konieczne ze względów porządku publicznego lub bezpieczeństwa publicznego. Rozporządzenie o zawieszeniu działalności sądów przysięgłych wydawała Rada Ministrów za zgodą Prezydenta Rzeczypospolitej. Odrębne przepisy zostały ustanowione w kodeksie w zakresie postępowania przed sądem grodzkim. Miało ono bowiem charakter uproszczony w stosunku do postępowania zwykłego obowiązującego przed innymi sądami, w szczególności przed sądem okręgowym ${ }^{22}$.

Od wyroków sądów grodzkich oraz okręgowych wydanych w pierwszej instancji strony mogły założyć apelację. Oskarżyciel posiłkowy nie mógł jednak podważyć wymiaru kary. Prokurator mógł wnieść apelację także na korzyść oskarżonego. Podstawy apelacji nie zostały ściśle określone. Sąd rozpoznający sprawę z powodu apelacji złożonej na korzyść od wyroku uniewinniającego w sprawie o przestępstwo ścigane $z$ urzędu był zobowiązany przeprowadzić od nowa całe postępowanie dowodowe. Odczytywanie protokołów z przesłuchania w pierwszej instancji było dopuszczalne tylko w przypadkach, w których możliwe było odczytywanie protokołów również w sądzie pierwszej instancji. Sąd odwoławczy nie mógł odmówić wezwania świadków i biegłych przesłuchanych w pierwszej instancji oraz sprowadzenia $\mathrm{z}$ sądu pierwszej instancji dowodów rzeczowych, jeżeli strona w apelacji w uzasadniony sposób zarzuciła nieścisłości protokołu albo żądała ponownego przesłuchania na okoliczność potwierdzenia faktów nieujawnionych w protokole, a mogących wpłynąć na orzeczenie o winie. Sąd odwoławczy tylko wtedy mógł odmówić przyjęcia nowego dowodu wskazanego w apelacji, gdy okoliczności, na które został powołany, nie mogły mieć wpływu na treść wyroku. Apelację rozpoznawano w granicach skargi, z wyjątkiem przypadków wskazanych w ustawie. $\mathrm{W}$ postępowaniu apelacyjnym obowiązywał zakaz reformationis in peius. Na po-

21 Dz.U. z 1928 r. Nr 12, poz. 93 z późn. zm.

22 W. Daszkiewicz, K. Paluszyńska-Daszkiewicz, Proces karny i materialne prawo karne w Polsce w latach 1918-1939, Torun 1965, s. 36. 
stanowienia sądu i zarządzenia prezesa zamykające drogę do wydania wyroku oraz w innych przypadkach wskazanych w ustawie przysługiwało zażalenie ${ }^{23}$.

Środki odwoławcze (zażalenia i apelacje) od orzeczeń sądów grodzkich rozpoznawał sąd okręgowy ${ }^{24}$, a od orzeczeń sądów okręgowych — sąd apelacyjny ${ }^{25}$.

Od wyroków wydanych w drugiej instancji, od wyroków sądów przysięgłych ${ }^{26}$ oraz od wyroków sądów pierwszej instancji w sprawach karno-administracyjnych przysługiwała kasacja. Jeżeli nie została ona sporządzona przez prokuratora, powinna była zostać podpisana przez osobę legitymującą się kwalifikacjami obrońcy. Do pisma procesowego należało dołączyć dowód opłacenia kaucji w wysokości 100 złotych, pod rygorem odmowy przyjęcia do rozpoznania. Od obowiązku wpłacenia kaucji zwolnieni byli oskarżeni przebywający w areszcie, skazani na karę pozbawienia wolności powyżej dwóch lat, osoby, którym sąd przyznał prawo ubogich, dłużnicy upadli oraz urzędy państwowe i samorządowe. Kasację można było oprzeć tylko na ściśle określonych podstawach, to jest na zarzutach nieprawidłowego zastosowania ustawy przy określeniu przestępstwa i wymiarze kary oraz obrazy przepisów postępowania. W razie złożenia kasacji na korzyść oskarżonego obowiązywał zakaz reformationis in peius. Prokurator Sądu Najwyższego „w obronie ustawy” mógł założyć kasację od każdego prawomocnego orzeczenia, jej celem było ustalenie należytej wykładni prawa ${ }^{27}$. Instancją kasacyjną był Sąd Najwyższy ${ }^{28}$.

Wkrótce po uchwaleniu kodeksu w piśmiennictwie prawniczym rozpoczęła się ożywiona dyskusja w sprawie radykalnej reformy procesu karnego w kierunku przyspieszenia i uproszczenia postępowania, rozszerzenia jednoosobowego orzekania, uszczuplenia - przesadnych, jak podnoszono - gwarancji procesowych oskarżonego, a także zmniejszenia liczby instancji ${ }^{29}$. Postulaty te zostały w znacznej części zrealizowane $\mathrm{w}$ trzech kolejnych nowelizacjach kodeksu postępowania karnego: z 21 stycznia 1932 roku $^{30}, 23$ sierpnia 1932 roku $^{31}$ oraz 21 listopada 1938 roku $^{32}$. Ich celem było przyspieszenie postępowania przez ograniczenie zasady

23 Ibidem, s. 36-37.

24 Art. 18 k.p.k. z 1928 r.

25 Art. 22 k.p.k. z 1928 r.

26 W myśl art. 20 k.p.k. z 1928 r. sąd okręgowy z udziałem przysięgłych, jako sąd przysięgłych, rozpoznawał sprawy: a) o przestępstwa, za które ustawa przewidywała karę śmierci lub bezterminowego pozbawienia wolności; b) o przestępstwa, za które najniższy ustawowy wymiar kary wynosił dziesięć lat pozbawienia wolności; c) o przestępstwa, które ustawa uznała za polityczne.

27 W. Daszkiewicz, K. Paluszyńska-Daszkiewicz, op. cit., s. 37.

28 Art. 23 k.p.k. z 1928 r.

29 W. Daszkiewicz, K. Paluszyńska-Daszkiewicz, op. cit., s. 39.

30 Ustawa z dnia 21 stycznia 1932 roku zmieniająca niektóre przepisy postępowania karnego (Dz.U. z 1932 r. Nr 10, poz. 60).

31 Rozporządzenie Prezydenta Rzeczypospolitej z dnia 23 sierpnia 1932 roku zmieniające niektóre przepisy postępowania karnego (Dz.U. z 1932 r. Nr 73, poz. 662).

32 Dekret Prezydenta Rzeczypospolitej z dnia 21 listopada 1938 roku o usprawnieniu postępowania sądowego (Dz.U. z 1938 r. Nr 89, poz. 609).

Prawo 328, 2019

(C) for this edition by CNS 
bezpośredniości, wprowadzenie utrudnień w zaskarżalności wyroków, rozszerzenie orzekania w składzie jednoosobowym, wyeliminowanie czynnika społecznego, wzmocnienie stanowiska prokuratora i ograniczenie uprawnień pokrzywdzonego ${ }^{33}$.

W ramach nowelizacji kodeksu z 21 stycznia 1932 roku uchylony został przepis, na podstawie którego sąd apelacyjny musiał od nowa przeprowadzić całe postępowanie dowodowe $\mathrm{w}$ razie apelacji od wyroku uniewinniającego w sprawie o przestępstwo ścigane $\mathrm{z}$ urzędu. Nawet dowód bezpodstawnie odrzucony przed rozprawą przez sąd pierwszej instancji mógł po styczniowej nowelizacji zostać odrzucony przez sąd odwoławczy. Na gruncie rozporządzenia Prezydenta Rzeczypospolitej z 23 sierpnia 1932 roku zniesiono zakaz reformationis in peius w razie uchylenia wyroku przez Sąd Najwyższy w postępowaniu kasacyjnym. Z kolei dekret Prezydenta Rzeczypospolitej z 21 listopada 1938 roku wprowadził nowy obowiązek dołączenia do zapowiedzi kasacji dowodu wpłaty zaliczki na poczet kaucji kasacyjnej w wysokości jednej czwartej całej kwoty. Jeżeli pismo procesowe nie zostało złożone, zaliczka nie podlegała zwrotowi. Równocześnie zwiększono wysokość kaucji, która w sprawach należących do sądów grodzkich wynosiła 100 złotych, w pozostałych zaś - 300 złotych. Ograniczono przy tym krąg osób zwolnionych z obowiązku opłacenia kaucji. W szczególności przywilej ten utraciły osoby skazane na karę pozbawienia wolności powyżej dwóch lat. Nowela z 1938 roku rozszerzyła także przesłanki rozpatrzenia kasacji na posiedzeniu niejawnym ${ }^{34}$. Należy podkreślić, że w okresie międzywojennym nie została zrealizowana stale ponawiana $\mathrm{w}$ piśmiennictwie propozycja zniesienia apelacji i przekształcenia postępowania trójinstancyjnego w dwuinstancyjne ${ }^{35}$. Pojawiła się ona również w trakcie obrad III Zjazdu Prawników Polskich w Katowicach w dniach 5-9 listopada 1936 roku $^{36}$. Ustawą z dnia 9 kwietnia 1938 roku zniesiono natomiast instytucję sądów przysięgłych ${ }^{37}$.

Kodeks postępowania karnego z 1928 roku, podobnie jak inne przepisy prawa $\mathrm{z}$ okresu międzywojennego, został utrzymany w mocy także po przejęciu władzy przez obóz polityczny skupiony wokół Polskiej Partii Robotniczej. W latach 1944-1948 wprowadzono do kodeksu pewne zmiany dotyczące kolejno: rozstrzygania sporów kompetencyjnych z sądami wojskowymi ${ }^{38}$, trybu wykony-

33 Szerzej o nowelach z lat 1932 i 1938 zob. W. Daszkiewicz, K. Paluszyńska-Daszkiewicz, op. cit., s. 39-42.

34 Ibidem.

35 K. Bzowski, Jeszcze o liczbie instancji w postępowaniu karnym, „Gazeta Sądowa Warszawska” 1936, nr 42; idem, Dwie czy trzy instancje w postepowaniu karnym, „Głos Sądownictwa” $1936, \mathrm{nr} 5$.

36 W. Daszkiewicz, K. Paluszyńska-Daszkiewicz, op. cit., s. 42.

37 Ustawa z dnia 9 kwietnia 1938 roku o zniesieniu instytucji sądów przysięgłych i sędziów pokoju (Dz.U. z 1938 r. Nr 24, poz. 213).

38 Art. 82 dekretu Polskiego Komitetu Wyzwolenia Narodowego (PKWN) z dnia 23 września 1944 roku Prawo o ustroju Sądów Wojskowych i Prokuratury Wojskowej (Dz.U. z 1944 r. Nr 6, poz. 29). 
wania kary śmierci ${ }^{39}$, postępowania $\mathrm{w}$ wypadku zaginięcia lub zniszczenia akt ${ }^{40}$, sporządzania protokołów ${ }^{41}$, opłat sądowych ${ }^{42}$ oraz wynikające $\mathrm{z}$ wejścia w życie nowego Prawa karnego skarbowego ${ }^{43}$. Miały one jednak ograniczony, fragmentaryczny charakter, nienaruszający modelu procesu wypracowanego zasadniczo w toku obrad Komisji Kodyfikacyjnej i ostatecznie ukształtowanego w ramach wskazanych trzech nowelizacji dokonanych przed wybuchem II wojny światowej $^{44}$. Z kolei dekretem PKWN z 15 sierpnia 1944 roku o wprowadzeniu sądów przysięgłych $^{45}$ uchylono ustawę z 9 kwietnia 1938 roku o zniesieniu instytucji sądów przysięgłych i sędziów pokoju ${ }^{46}$. Dekret ten - mimo podjętych przygotowań - nie został w praktyce wykorzystany, a istotną tego przyczyną było rozpoczęcie realizacji koncepcji udziału ławników w postępowaniu karnym ${ }^{47}$. Formalnie został on uchylony na mocy art. 2 pkt 2 ustawy z 27 kwietnia 1949 roku o zmianie prawa o ustroju sądów powszechnych ${ }^{48}$.

Ustawodawca Polski Ludowej utrzymał wprawdzie moc obowiązującą k.p.k. z 1928 roku, ale jednocześnie wydawał nowe akty prawne, w których w odmienny sposób normował postępowanie karne w sprawach niektórych przestępstw. Na podstawie dekretu z 12 września 1944 roku $^{49}$ zostały utworzone specjalne sądy karne właściwe w sprawach przestępstw ujętych w dekrecie PKWN z 31 sierpnia 1944 roku, popularnie zwanym ,sierpniówką” lub „dekretem sierpniowym”,

39 Dekret PKWN z dnia 1 grudnia 1944 roku o częściowej zmianie kodeksu postępowania karnego (Dz.U. z 1944 r. Nr 13, poz. 70).

40 Dekret z dnia 6 czerwca 1945 roku o zmianie przepisów kodeksu postępowania karnego (Dz.U. z 1945 r. Nr 25, poz. 148).

41 Dekret z dnia 19 sierpnia 1946 roku o zmianie niektórych przepisów postępowania karnego (Dz.U. z 1946 r. Nr 43, poz. 249).

42 Dekret z dnia 23 stycznia 1947 roku o opłatach sądowych w sprawach karnych (Dz.U. z 1947 r. Nr 19, poz. 73) oraz dekret z dnia 3 kwietnia 1948 roku o zmianie kwot pieniężnych w przepisach kodeksu postępowania karnego (Dz.U. z 1948 r. Nr 20, poz. 136).

43 Art. 305 „Przepisów przejściowych i końcowych” dekretu z dnia 11 kwietnia 1947 roku Prawo karne skarbowe (Dz.U. z 1947 r. Nr 32, poz. 140).

44 Obwieszczenie Ministra Sprawiedliwości z dnia 16 stycznia 1939 roku o ogłoszeniu jednolitego tekstu kodeksu postępowania karnego (Dz.U. z 1939 r. Nr 8, poz. 44).

45 Dz.U. z 1944 r. Nr 2, poz. 7.

46 Więcej zob. A. Pasek, Zasada udziału czynnika społecznego w procesie karnym w początkach Polski Ludowej, [w:] Zasady prawne w dziejach prawa publicznego i prywatnego, red. M. Podkowski, Wrocław 2015, s. 187.

47 A. Lityński, O prawie i sądach początków Polski Ludowej, Białystok 1999, s. 134. Zob. także A. Pasek, Zasada udziału..., s. 188.

48 Dz.U. z 1949 r. Nr 32, poz. 237.

49 Dekret PKWN z dnia 12 września 1944 roku o specjalnych sądach karnych dla spraw zbrodniarzy faszystowsko-hitlerowskich (Dz.U. z 1944 r. Nr 4, poz. 21).

50 Dekret PKWN z dnia 31 sierpnia 1944 roku o wymiarze kary dla faszystowsko-hitlerowskich zbrodniarzy winnych zabójstw i znęcania się nad ludnością cywilną i jeńcami wojennymi oraz dla zdrajców Narodu Polskiego (tekst jedn. Dz.U. z 1946 r. Nr 69, poz. 377 z późn. zm.). 
oraz w sprawach o odstępstwo od narodowości ${ }^{51}$. W myśl art. 6 dekretu postępowanie przed specjalnym sądem karnym odbywało się według przepisów kodeksu postępowania karnego, o ile jego przepisy nie zawierały odmiennych postanowień. Tymczasem art. 18 stanowił, że wyroki specjalnego sądu karnego są ostateczne i prawomocne. Postępowanie było zatem jednoinstancyjne. Dopiero po utworzeniu Najwyższego Trybunału Narodowego (NTN) na podstawie dekretu z 22 stycznia 1946 roku $^{52}$ podważano zasadę jednoinstancyjności, ponieważ stosownie do art. 15 tegoż dekretu Pierwszy Prokurator NTN mógł w ciągu trzech miesięcy zaskarżyć każdy wyrok specjalnego sądu karnego, jeśli istniały podstawy kasacji wskazane w art. 510 i 514-516 k.p.k. lub podstawy do wznowienia postępowania z art. 600 i 602 k.p.k. Natomiast z mocy art. 15 dekretu wyroki i postanowienia NTN były ostateczne. Postępowanie w sprawach podlegających jurysdykcji trybunału na mocy art. 6 dekretu także miało zatem charakter jednoinstancyjny ${ }^{53}$.

Przedwojennej zasady trójinstancyjności nie znał również dekret z 16 listopada 1945 roku o przestępstwach szczególnie niebezpiecznych w okresie odbudowy państwa ${ }^{54}$. W myśl art. 38 pkt 4 lit. c)-e) dekretu w sprawach opisanych w nim przestępstw od wyroków sądów okręgowych służyła stronom tylko kasacja do Sądu Najwyższego. Jeżeli Sąd Najwyższy uznał, że nie ma obrazy przepisów postępowania określonej w art. 514 i 515 k.p.k. z 1928 roku, a zachodziło nieprawidłowe zastosowanie ustawy przy określeniu przestępstwa i wymiarze kary, mógł wyrok uchylić i sam orzec co do istoty sprawy zamiast przekazywać ją do ponownego rozpoznania. Sąd Najwyższy nie był w tym wypadku związany karą orzeczoną w zaskarżonym wyroku, był natomiast związany ustalonym w nim stanem faktycznym. Poza przypadkami przewidzianymi w k.p.k. Sąd Najwyższy uchylał wyrok sądu okręgowego, jeżeli powziął poważne wątpliwości co do prawidłowości ustaleń faktycznych przyjętych za podstawę zaskarżonego wyroku. Analogiczne przepisy zawierały art. 61-63 dekretu z 13 czerwca 1946 roku o przestępstwach szczególnie niebezpiecznych w okresie odbudowy państwa ${ }^{55}$. Mały kodeks karny — zarówno w wersji z 1945 roku, jak i z 1946 roku — znosił zatem apelację, konstruując postępowanie instancyjne o specyficznym charakterze, łączące elementy apelacji i kasacji, zbliżone do późniejszego trybu rewizyjnego ${ }^{56}$.

Jednocześnie $\mathrm{z}$ wprowadzaniem do porządku prawnego wskazanych specjalnych trybów postępowania rozpoczęto przygotowania do przeprowadzenia

51 Dekret z dnia 28 czerwca 1946 roku o odpowiedzialności karnej za odstępstwo od narodowości w czasie wojny 1939-1945 roku (Dz.U. z 1946 r. Nr 41, poz. 237 z późn. zm.).

52 Dekret z dnia 22 stycznia 1946 roku o Najwyższym Trybunale Narodowym (tekst jedn. Dz.U. z 1946 r. Nr 59, poz. 327 z późn. zm.).

53 Szerzej zob. A. Pasek, Przestepstwa okupacyjne w polskim prawie karnym z lat 1944-1956, „Prawo” 325, 2002, s. 182-189.

54 Dz.U. z 1945 r. Nr 53, poz. 300.

55 Dz.U. z 1946 r. Nr 30, poz. 192 z późn. zm.

56 M. Kallas, A. Lityński, Historia ustroju i prawa Polski Ludowej, Warszawa 2000, s. 318. 
zasadniczych zmian w powszechnej procedurze karnej, w tym dotyczących instancyjności postępowania. Główną rolę odgrywały w tej sprawie wypowiedzi urzędników ministerstwa sprawiedliwości, stanowiące pretekst do rozważań na temat wadliwości rozwiązań zastosowanych w kodeksie postępowania karnego z 1928 roku oraz inspirujące do zgłaszania w tym zakresie własnych postulatów przez przedstawicieli praktyki i doktryny prawa.

Przede wszystkim należy wskazać na referat wygłoszony przez Mariana Muszkata 12 listopada 1945 roku na zebraniu dyskusyjnym oddziału warszawskiego Zrzeszenia Prawników Demokratów, w którym przekonywał słuchaczy między innymi o konieczności zniesienia instytucji apelacji. Argumentował, że nadmiar instancji powoduje ,przeciąganie spraw latami”, a ,wymiar sprawiedliwości tylko wtedy spełnia swoje zadanie, gdy jest szybki". Argumentował, że rozpatrywanie sprawy przez trzy instancje „nie posiada rzeczowego uzasadnienia”, ponieważ karanie ludzi po wielu latach od popełnienia przestępstwa nie wpływa korzystnie na poczucie sprawiedliwości. M. Muszkat podnosił, że nadmiar instancji jako zabezpieczenie przed pomyłkami sądowymi, zwłaszcza polegającymi na skazywaniu osób niewinnych, nie zapewnia oczekiwanych wyników. Skuteczniejsza jego zdaniem byłaby rezygnacja $\mathrm{z}$ apelacji i wprowadzenie dwóch instancji: merytorycznej i rewizyjnej ${ }^{57}$.

Z propozycjami Muszkata zbieżne było stanowisko ministra sprawiedliwości Henryka Świątkowskiego, który omawiając „prace i zamierzenia” resortu planowane w 1946 roku, wymienił ,przygotowanie szeregu dekretów, których opracowania bądź nowelizacji domagała się współczesna rzeczywistość”, w tym zasadniczą zmianę kodeksu postępowania karnego ${ }^{58}$. Nadmienił przy tym, że niezbędne jest usprawnienie wymiaru sprawiedliwości i przyspieszenie postępowania, „co dałoby się uskutecznić przez zniesienie drugiej instancji w sprawach karnych i zastąpienie jej jedną instancją merytoryczną i drugą rewizyjno-kasacyjną, którą byłby Sąd Najwyższy"59.

Za głęboką reformą procedury karnej opowiadał się również pierwszy prezes Sądu Najwyższego Wacław Barcikowski. On także uważał, że wśród „szeregu problemów na czoło wysuwa się kwestia wieloinstancyjności procesu sądowego”. W. Barcikowski pisał, że byłyby wskazane „duże ograniczenia” rodzaju spraw przechodzących do wyższych instancji oraz terminów ich rozpoznania. Za „niewątpliwy argument przemawiający za zniesieniem wieloinstancyjności” uznawał „rozpowszechnione w społeczeństwie naszym pieniactwo i złośliwe przewlekanie procesu”. Krytycznie oceniał, że ,przynosi to ujmę wymiarowi sprawiedliwości w opinii publicznej i zniechęca doń społeczeństwo", dlatego z tego rodzaju zjawiskiem należy zdecydowanie walczyć poprzez zmiany w obowiązującym prawie ${ }^{60}$.

57 M. Muszkat, O reformę ustroju sądownictwa i prokuratury, „Demokratyczny Przegląd Prawniczy" (dalej: DPP) 1945, nr 2, s. 28.

58 H. Świątkowski, Prace i zamierzenia Ministerstwa Sprawiedliwości, DPP 1946, nr 1, s. 4.

59 Ibidem.

60 W. Barcikowski, Ważniejsze zagadnienia ustawodawcze, DPP 1946, nr 2, s. 4. 
Z kolei pierwszy prokurator Sądu Najwyższego Mieczysław Siewierski w referacie wygłoszonym na zebraniu dyskusyjnym Zrzeszenia Prawników Demokratów w Warszawie podkreślał, że „reformy sięgające daleko w przyszłość wymagają wielkiej rozwagi i staranności w przygotowaniu, a ponadto muszą dojrzeć w opinii publicznej”. Do zagadnień „dojrzałych w opinii prawnictwa polskiego do realizacji” zaliczył także ograniczenie procesu do dwóch instancji: jednej merytorycznej, a drugiej rewizyjno-kasacyjnej ${ }^{61}$.

Zniesienie apelacji — głosił Siewierski — jedno z najbardziej niegdyś spornych zagadnień, nie budziło już w jego ocenie wątpliwości. Wskazywał, że z kolei powołanie ławników dodatkowo wzmacnia argumentację na rzecz ustanowienia tylko jednej instancji merytorycznej, ponieważ odwołanie od jednego zespołu prawniczego do drugiego nie jest logicznie uzasadnione. Natomiast jedyny argument przytaczany za utrzymaniem apelacji, czyli konieczność korekty nieprawidłowych wyroków sądów pierwszej instancji, przemawiał za koniecznością merytorycznego badania sprawy w ramach kontroli rewizyjnej. Jedyna instancja odwoławcza po zniesieniu apelacji — Sąd Najwyższy — nie mogła zatem odgrywać wyłącznie roli sądu kasacyjnego, ale po spełnieniu określonych przesłanek musiała dysponować również prawem do merytorycznej oceny orzeczenia na podstawie przedłożonych akt sprawy ${ }^{62}$.

Z różnych istniejących systemów Siewierski rekomendował system przyjęty w obowiązującej poprzednio polskiej procedurze wojskowej. Wprowadzenie tego systemu do sądów powszechnych miało przyspieszyć sądzenie, którego powolność uważał za „piętę achillesową polskiego sądownictwa”. Dostrzegał, że wprowadzenie tego systemu w życie nie byłoby łatwym zadaniem, skoro wówczas Sąd Najwyższy stałby się drugą instancją we wszystkich sprawach karnych. Rozwiązaniem tego problemu byłoby utworzenie za wzorem francuskim Izby Wstępnej. Jej usytuowanie w siedzibie Sądu Najwyższego lub w siedzibach istniejących wtedy sądów apelacyjnych uznał ,za kwestię poniekąd techniczną" ${ }^{63}$.

Ministerstwo sprawiedliwości zorganizowało w dniach 16-17 listopada 1946 roku konferencję poświęconą omówieniu tez do reformy ustroju i postępowania sądowego. Przedstawione wówczas propozycje wprawdzie nie wyrażały jeszcze oficjalnego stanowiska ministerstwa, ale świadczyły o pewnej krystalizacji poglądów w sprawie planowanej reformy, w tym nowelizacji kodeksu postępowania karnego. Podstawowe tezy przedstawił dyrektor Biura Personalnego Ministerstwa Sprawiedliwości Józef Ordyniec. Na wstępie swojego wystąpienia urzędnik ministerialny wskazał, że konieczność przeprowadzenia reformy wynikała przede wszystkim

61 M. Siewierski, O reformę wymiaru sprawiedliwości w dziedzinie karnej, DPP 1946, nr 2, s. 36.

62 Ibidem, s. 37.

63 Ibidem. 
z dokonanego w Polsce przewrotu społeczno-gospodarczego w drodze tzw. łagodnej rewolucji i przejścia od systemu gospodarki liberalno-kapitalistycznej XIX w. do gospodarki planowej i uspołecznionej o typie nazwanym w środkowej Europie demokracją ludową. W ślad za tym przewrotem musiała pójść rezygnacja z instytucji ustrojowych i procesowych, tkwiących korzeniami w zeszłowiecznym liberalizmie, a będących przedmiotem konserwatywnego przywiązania znacznej części prawnictwa w Polsce ${ }^{64}$.

Do tego rodzaju instytucji zaliczył zasadę trójinstancyjności orzekania.

Zniesienie drugiej merytorycznej instancji było jednym z głównych tematów konferencji. W trakcie dyskusji przedstawiciele doktryny i praktyki prawa karnego w znakomitej większości poparli ten postulat. Pewne zastrzeżenia zgłosił jedynie sędzia Sądu Najwyższego Antoni Landau, według którego „twierdzenie, że należy skasować drugą instancję merytoryczną jako zbędne i szkodliwe ogniwo w toku instancji sądowych, wydaje się nieco śmiałym, jak zresztą każde oświadczenie bez motywów, odrzucające wyniki pracy naukowej setek i tysięcy ludzi”. Przypomniał ponadto, że „sprawa ilości instancji jest tak stara, jak same instancje, i potrzeba by nie jednej sali, żeby pomieścić chociażby tylko to, co mądrze na ten właśnie temat napisano, dochodząc do różnych jednak wniosków"65.

W ramach dyskusji w sprawie reformy wymiaru sprawiedliwości za utrzymaniem systemu pełnej apelacji od wyroku sądu pierwszej instancji, a więc za utrzymaniem drugiej instancji merytorycznej, zdecydowanie opowiedział się także profesor Katolickiego Uniwersytetu Lubelskiego Zdzisław Papierkowski. W artykule opublikowanym na łamach „Demokratycznego Przeglądu Prawniczego” uczony ostrzegał, że ,nawet ludzie bardzo rozsądni błądzą przy ustalaniu okoliczności faktycznych”. Dalej argumentował, że „nie może być za dużo ostrożności, gorliwości i wydatków pieniężnych tam, gdzie chodzi o możliwie najtrafniejsze i najsłuszniejsze orzeczenie sądowe, od którego zależy czasem życie, a zawsze jakieś inne dobro obywatela" ${ }^{66}$. Profesor Papierkowski podnosił również, że „Rzeczpospolita Polska jest państwem demokratycznym i jako taka jest powołana do strzeżenia i pomnażania tego wszystkiego, co określamy wspólnym mianem demokratycznych zdobyczy obywatelskich". Za jedną z takich fundamentalnych zdobyczy lubelski uczony uważał

prawo obywatela do żądania od wymiaru sprawiedliwości, aby dawał jak najwięcej gwarancji w tym kierunku, iż nie pominięto żadnej okazji do jak najbardziej skrupulatnego rozpatrzenia jego sprawy, kiedy stanie przed sądem pod zarzutem wejścia w konflikt $\mathrm{z}$ obowiązującym prawem karnym.

Druga instancja merytoryczna w procesie karnym była — według Z. Papierkowskiego — jedną z takich zdobyczy, o które „walczył obywatel i całe społeczeństwo na przestrzeni dziesiątek lat i które udało się tu i ówdzie wywalczyć" 67 .

\footnotetext{
64 Konferencja w sprawie reformy ustroju i postepowania sądowego, DPP 1947, nr 4, s. 12.

65 Ibidem.

66 Z. Papierkowski, W sprawie reformy wymiaru sprawiedliwości, DPP 1947, nr 9, s. 25.

67 Ibidem, s. 26.
} 
Kolejnym krokiem planowanych reform w zakresie ustroju i prawa karnego było powołanie Komisji Kodyfikacji Prawa Karnego. Pod przewodnictwem ministra sprawiedliwości Henryka Świątkowskiego 4 października 1947 roku odbyło się jej pierwsze, organizacyjne zebranie w sali konferencyjnej ministerstwa sprawiedliwości. W inauguracyjnym przemówieniu minister Świątkowski stwierdził, że w dziedzinie postępowania karnego prace powinny zmierzać do jego uproszczenia i przyspieszenia z zagwarantowaniem praw pokrzywdzonego, ale bez uszczerbku w zakresie uprawnień oskarżonego. Te ostatnie „nie powinny być jednak przywilejem utrudniającym represję karną tam, gdzie udowodniono winę" 68 .

Komisja obradowała plenarnie i w ramach czterech sekcji; jedną z nich była sekcja procedury karnej ${ }^{69}$. W pełnym składzie zbierała się raz w miesiącu pod przewodnictwem ministra sprawiedliwości lub osoby przez niego wyznaczonej. Do jej kompetencji należało wysłuchiwanie sprawozdań poszczególnych sekcji oraz rozstrzyganie kwestii spornych w gronie ich członków ${ }^{70}$.

Efektem prowadzonych prac były skierowane do Sejmu rządowe projekty ustaw dotyczących sądownictwa, obejmujące także reformę sądowego postępowania karnego. Ich założenia zostały omówione przez ministra sprawiedliwości w trakcie przemówienia wygłoszonego w Sejmie 30 marca 1948 roku. Wśród celów projektowanej reformy H. Świątkowski wymienił między innymi przyspieszenie wymiaru sprawiedliwości. Wskazał, że szybkość postępowania sądowego była „hamowana” przez system trzech instancji. Z tego powodu w miejsce drugiej instancji apelacyjnej i trzeciej instancji kasacyjnej zaproponowano jedną instancję odwoławczą. Minister uspokajał, że mimo zniesienia trzeciej instancji strony nie doznają istotnego ,uszczuplenia” swoich praw, ponieważ instancja odwoławcza będzie rozpatrywała obie kategorie zarzutów, które uprzednio odwołujący się mógł składać kolejno sądowi apelacyjnemu i sądowi kasacyjnemu. Minister zwrócił też uwagę, że proponowane ograniczenia toku postępowania karnego do dwóch instancji sądowych funkcjonowały w Polsce Ludowej już od kilku lat na gruncie ustaw szczególnych zawierających odrębne od kodeksowych przepisy procesowe. Przypomniał, że w trybie dwuinstancyjnym rozpoznawano sprawy „o spowodowanie klęski wrześniowej i faszyzację życia państwowego”, o zbrodnie faszystowsko-hitlerowskie, o odstępstwo od narodowości polskiej oraz o sprawy z tak zwanego małego kodeksu karnego. Minister Świątkowski wskazał, że po zniesieniu trzeciej instancji sądowej interes publiczny zostanie dodatkowo zabezpieczony nową instytucją — nadzwyczajną skargą rewizyjną ${ }^{71}$.

68 Zebranie organizacyjne Komisji Kodyfikacji Prawa Karnego, DPP 1947, nr 10, s. 41.

69 W skład sekcji procedury karnej weszli: prokurator Tadeusz Cyprian (przewodniczący); urzędnicy Ministerstwa Sprawiedliwości: Leszek Lernell (zastępca przewodniczącego), Zygmunt Kapitaniak, Stefan Bancerz, Józef Ordyniec; prokurator Mieczysław Siewierski, prof. Stanisław Śliwiński, prof. Jan Wasilkowski oraz adwokaci Jarosz, Karniol i Maślanko — ibidem, s. 42.

70 Ibidem.

71 H. Świątkowski, Reformy w dziedzinie prawa karnego, DPP 1949, nr 4, s. 5. 
Uchwalona przez Sejm ustawa z dnia 27 kwietnia 1949 roku o zmianie przepisów postępowania karnego ${ }^{72}$ wprowadzała istotne zmiany do kodeksu z 1928 roku, nie pretendując jednak do kompleksowego rozwiązania wszystkich problemów sygnalizowanych w wystąpieniach poprzedzających jej opracowanie. W założeniu inicjatorów stanowiła ona jedynie pierwszy etap całkowitej przebudowy procedury sądowej. Przygotowana nowela do kodeksu z 1928 roku była pierwszą po wojnie zasadniczą reformą procedury karnej. Jej projektodawcy nie ukrywali, że celem było nie tylko przyspieszenie, uproszczenie i usprawnienie powszechnego wymiaru sprawiedliwości w sprawach karnych, lecz także stworzenie lepszych podstaw prawnych dla organów wymiaru sprawiedliwości do realizacji zadań „,na obecnym etapie zaostrzającej się walki klasowej” przeciwko „wszelkim zamachom na interesy społeczne, gospodarcze i polityczne naszego państwa ludowego"73.

Na gruncie obowiązujących uprzednio przepisów k.p.k. z 1928 roku drobne sprawy karne należały do właściwości rzeczowej sądów grodzkich, wszystkie zaś inne sprawy karne rozpoznawały sądy okręgowe. Na gruncie noweli do k.p.k. z 1928 roku uznano jednak, że pozostawienie wszystkich bez wyjątku poważniejszych spraw w kompetencji pięćdziesięciu siedmiu sądów okręgowych i oddziałów zamiejscowych nie zapewni ,słusznego z punktu widzenia ochrony interesów państwa ludowego" wymiaru sprawiedliwości. Wśród podlegających jurysdykcji sądom okręgowym znajdowały się bowiem najcięższe sprawy o „szczególnej doniosłości społeczno-gospodarczej”, które powinny być rozstrzygane przez sąd wyższego rzędu w hierarchii sądownictwa powszechnego. „Słuszne z punktu widzenia interesów mas ludowych rozstrzyganie tych spraw" wymagało od sędziów „szczególnie wysokiego uświadomienia politycznego i wszechstronnej orientacji w aktualnej problematyce gospodarczej i społecznej". Należało również uwzględnić zawiły charakter tego typu spraw pod kątem prawnym, celowe było zatem rozpoznawanie ich przez doświadczonych sędziów. Nowelizacja zmieniła więc kompetencje sądów pierwszej instancji. Sprawy karne najważniejsze z punktu widzenia interesów gospodarczych, politycznych i społecznych państwa zostały przekazane w pierwszej instancji sądom apelacyjnym. Według noweli sąd apelacyjny rozpoznawał: 1. sprawy o aspekcie politycznym; 2. sprawy gospodarcze, w których interes Polski został narażony na znaczną szkodę; 3. sprawy o zbrodnie faszystowsko-hitlerowskie; 4. sprawy o inne ciężkie przestępstwa, które w konkretnych warunkach winny być uznane za szczególnie groźnie ${ }^{74}$.

W ustawie nowelizującej k.p.k. z 1928 roku odzwierciedlona została silna krytyka systemu trójinstancyjnego (sąd pierwszej instancji-sąd apelacyjny-Sąd Najwyższy), obciążanego odpowiedzialnością za przewlekłość procesu sądowe-

72 Dz.U. z 1949 r. Nr 32, poz. 238.

73 Uzasadnienie rzadowe do projektu zmiany kodeksu postępowania karnego, DPP 1949, nr 6-7, s. 6-7.

74 Ibidem, s. 8. 
go, a tym samym „stępienie miecza wymiaru sprawiedliwości”75. Nowe przepisy skróciły zatem tok instancji z trzech do dwóch. Dotychczasowe dwie formy i dwa szczeble odwoławcze zastąpiono rewizją ${ }^{76}$ jako jedynym środkiem odwoławczym, łączącym elementy apelacji i kasacji. Punktem wspólnym rewizji z dawną apelacją była kontrola przez sąd odwoławczy wyroku pierwszej instancji nie tylko pod względem zgodności z przepisami prawa, lecz także w aspekcie jego słuszności, zgodności zarówno ze stanem faktycznym sprawy, jak i z zasadami represji karnej, odpowiadającymi ,interesom państwa ludowego”. Z kolei wspólne elementy rewizji z kasacją dotyczyły skierowania sprawy do ponownego rozpatrzenia w sądzie pierwszej instancji po uchyleniu wyroku z powodu wadliwego ustalenia stanu faktycznego. Argumentowano, że wydanie w takim wypadku ponownego wyroku — jak to miało miejsce w ramach postępowania apelacyjnego — przez sąd odwoławczy, który „nie widzi żywych ludzi w procesie”, a sądzi jedynie na podstawie dokumentów zgromadzonych w aktach sprawy, byłoby „zastosowaniem biurokratycznych metod dla oceny i kwalifikacji czynów żywych ludzi"77.

Ustawa nowelizacyjna ustanowiła także nowy, nadzwyczajny środek odwoławczy od każdego prawomocnego wyroku w postaci rewizji nadzwyczajnej ${ }^{78}$. W myśl art. 507 k.p.k. w brzmieniu ustalonym nowelą kodeksu z 27 kwietnia 1949 roku podmiotem uprawnionym do jej założenia w Sądzie Najwyższym był tylko Pierwszy Prokurator Sądu Najwyższego. Uwzględniając rewizję nadzwyczajną wniesioną na niekorzyść oskarżonego po upływie 6 miesięcy od dnia uprawomocnienia się orzeczenia, Sąd Najwyższy ograniczał się tylko do ustalenia uchybieńn ${ }^{79}$. Ten nadzwyczajny środek zaskarżenia mógł więc zostać uruchomiony w każdym czasie, ale mógł spowodować niekorzystne skutki prawne dla oskarżonego tylko wtedy, jeśli od uprawomocnienia się wyroku nie upłynęło 6 miesięcy. Powierzenie stosowania nadzwyczajnej rewizji wyłącznie Pierwszemu Prokuratorowi Sądu Najwyższego miało stanowić gwarancję, że środek ten będzie używany, jedynie gdy konieczne będzie skorygowanie „wręcz niesłusznego, aczkolwiek prawomocnego już wyroku" 80 .

Zasada dwuinstancyjności postępowania została ugruntowana w ustawie z dnia 20 lipca 1950 roku o zmianie przepisów postępowania karnego ${ }^{81}$. W myśl

75 „Trzeba tu zaznaczyć, że trzecia instancja jest wprawdzie tylko kasacyjna i sprawdza jedynie sprawę pod kątem widzenia oceny zgodności z prawem. W praktyce jednak kasacja na ogół wychodzi poza ramy ściśle prawniczych, formalnych kwestii, tak że każdą sprawę filtruje się trzykrotnie, co przyczynia się do niezmiernego przewlekania procesu. System ten jest wadliwy z punktu widzenia sprawności działania aparatu wymiaru sprawiedliwości, zwłaszcza na obecnym etapie walki klasowej" — ibidem, s. 9.

76 Szerzej o tej instytucji zob. J. Sawicki, M. Maślanko, Kontrola rewizyjna, DPP 1949, nr 6-7, s. $71-75$.

77 Uzasadnienie rzadowe..., s. 9.

78 Szerzej o tej instytucji zob. T. Cyprian, Rewizja nadzwyczajna, DPP 1949, nr 6-7, s. 77-79.

79 Dz.U. z 1949 r. Nr 32, poz. 238.

80 Uzasadnienie rzadowe..., s. 9.

81 Dz.U. z 1950 r. Nr 38, poz. 348.

Prawo 328, 2019

(C) for this edition by CNS 
art. 15 k.p.k. sąd powiatowy orzekał we wszystkich sprawach w pierwszej instancji, jeżeli nie były one przepisem szczególnym przekazane innemu sądowi. Na zasadzie art. 17 § 3 sąd wojewódzki rozpoznawał środki odwoławcze (zażalenia i rewizje) od orzeczeń sądów powiatowych. Stosownie do art. 19 § 1 Sąd Najwyższy rozpoznawał środki odwoławcze od orzeczeń sądów wojewódzkich ${ }^{82}$. Nowelizacja była związana z przebudową wymiaru sprawiedliwości, zapoczątkowaną w 1949 roku $^{83}$, w tym dalszymi zmianami struktury sądów powszechnych ${ }^{84}$ oraz nowych zasad funkcjonowania prokuratury ${ }^{85}$.

Należy w pełni podzielić pogląd, że obie nowelizacje kodeksu postępowania karnego z lat 1949-1950 stworzyły w istocie nową procedurę karną w porównaniu ze stanem prawnym ukształtowanym $\mathrm{w}$ okresie międzywojennym ${ }^{86}$. Jednym z ważnych elementów tych zmian była rezygnacja z trójinstancyjnego systemu apelacyjno-kasacyjnego na rzecz dwuinstancyjnego rewizyjnego. Wykorzystano tu doświadczenia zebrane na gruncie przepisów proceduralnych wprowadzonych uprzednio do dekretów z zakresu prawa karnego z lat 1944-1946 ${ }^{87}$. Zastosowana w nich po raz pierwszy zasada dwuinstancyjności została następnie recypowana do kodeksu postępowania karnego. W konsekwencji unormowanie o charakterze wyjątkowym nabrało charakteru zasady powszechnie obowiązującej; nie tylko zostało utrwalone w kodeksie postępowania karnego z 1928 roku, lecz także przejęte przez kodeks postępowania karnego z 1969 roku $^{88}$.

82 Obwieszczenie Ministra Sprawiedliwości z dnia 2 września 1950 roku o ogłoszeniu jednolitego tekstu kodeksu postępowania karnego (Dz.U. z 1950 r. Nr 40, poz. 364).

83 Zostały one zwięźle omówione w H. Świątkowski, Donioste reformy wymiaru sprawiedliwości, DPP 1950, nr 8-9, s. 3-5.

84 Ustawa z dnia 20 lipca 1950 roku o zmianie prawa o ustroju sądów powszechnych (Dz.U. z 1950 r. Nr 38, poz. 347).

85 Ustawa z dnia 20 lipca 1950 roku o Prokuraturze Rzeczypospolitej Polskiej (Dz.U. z 1950 r. $\mathrm{Nr} 38$, poz. 346).

86 M. Kallas, A. Lityński, op. cit., s. 326.

87 „Te nowe akty prawne odpowiadały założeniom nowego ustroju oraz celom, jakie ustawodawca stawiał przed prawem karnym materialnym i procesowym: ochrony ustroju i likwidacji wrogów klasowych. Unormowano więc odmiennie postępowanie karne w niemal wszystkich sprawach o dużym ciężarze gatunkowym, mającym zabarwienie polityczne. Nowe procedury w całości lub części pojawiały się w dokładnie w każdym akcie prawa karnego od pierwszych chwil funkcjonowania PKWN aż do połowy 1946 r., ,a w wielu aktach także później”ibidem, s. 315. Szerzej o tych regulacjach zob. M. Kallas, A. Lityński, op. cit., s. 293-307; A. Pasek, Odstepstwo od narodowości w polskim prawie karnym lat 1944-1945, „Prawo” 261, 1998, s. 198 n.; idem, Uwagi o źródłach polskiego prawa karnego materialnego z lat 1944-1950, [w:] W kręgu dziejów prawa karnego, red. P. Jurek, Wrocław 1999, s. 100 n.; idem, Dekret PKWN z 31 sierpnia 1944 r. (sierpniówka). Próba analizy historycznoprawnej, CPH 51, 1999, nr 1-2, s. 340-342; idem, Przestepstwa okupacyjne..., s. 182-187.

88 Ustawa z dnia 19 kwietnia 1969 roku Kodeks postępowania karnego (Dz.U. z 1969 r. Nr 38, poz. 96 z późn. zm.).

Prawo 328, 2019

(C) for this edition by CNS 


\section{Bibliografia}

\section{Źródła}

\section{Akty prawne}

Dekret PKWN z dnia 15 sierpnia 1944 roku o wprowadzeniu sądów przysięgłych (Dz.U. z 1944 r. Nr 2, poz. 7).

Dekret PKWN z dnia 31 sierpnia 1944 roku o wymiarze kary dla faszystowsko-hitlerowskich zbrodniarzy winnych zabójstw i znęcania się nad ludnością cywilną i jeńcami wojennymi oraz dla zdrajców Narodu Polskiego (tekst jedn. Dz.U. z 1946 r. Nr 69, poz. 377).

Dekret PKWN z dnia 12 września 1944 roku o specjalnych sądach karnych dla spraw zbrodniarzy faszystowsko-hitlerowskich (Dz.U. z 1944 r. Nr 4, poz. 21).

Dekret PKWN z dnia 23 września 1944 roku Prawo o ustroju Sądów Wojskowych i Prokuratury Wojskowej (Dz.U. z 1944 r. Nr 6, poz. 29).

Dekret PKWN z dnia 1 grudnia 1944 roku o częściowej zmianie kodeksu postępowania karnego (Dz.U. z 1944 r. Nr 13, poz. 70).

Dekret Prezydenta Rzeczypospolitej z dnia 21 listopada 1938 roku o usprawnieniu postępowania sądowego (Dz.U. z 1938 r. Nr 89, poz. 609).

Dekret z dnia 6 czerwca 1945 roku o zmianie przepisów kodeksu postępowania karnego (Dz.U. z 1945 r. Nr 25, poz. 148).

Dekret z dnia 16 listopada 1945 roku o przestępstwach szczególnie niebezpiecznych w okresie odbudowy Państwa (Dz.U. z 1945 r. Nr 53, poz. 300).

Dekret z dnia 22 stycznia 1946 roku o Najwyższym Trybunale Narodowym (tekst jedn. Dz.U. z 1946 r. $\mathrm{Nr} 59$, poz. 327).

Dekret z dnia 13 czerwca 1946 roku o przestępstwach szczególnie niebezpiecznych w okresie odbudowy Państwa (Dz.U. z 1946 r. Nr 30, poz. 192).

Dekret z dnia 28 czerwca 1946 roku o odpowiedzialności karnej za odstępstwo od narodowości w czasie wojny 1939-1945 roku (Dz.U. z 1946 r. Nr 41, poz. 237).

Dekret z dnia 19 sierpnia 1946 roku o zmianie niektórych przepisów postępowania karnego (Dz.U. z 1946 r. Nr 43, poz. 249).

Dekret z dnia 23 stycznia 1947 roku o opłatach sądowych w sprawach karnych (Dz.U. z 1947 r. Nr 19, poz. 73).

Dekret z dnia 11 kwietnia 1947 roku Prawo karne skarbowe (Dz.U. z 1947 r. Nr 32, poz. 140).

Dekret z dnia 3 kwietnia 1948 roku o zmianie kwot pieniężnych w przepisach kodeksu postępowania karnego (Dz.U. z 1948 r. Nr 20, poz. 136).

Obwieszczenie Ministra Sprawiedliwości z dnia 16 stycznia 1939 roku o ogłoszeniu jednolitego tekstu kodeksu postępowania karnego (Dz.U. z 1939 r. Nr 8, poz. 44).

Rozporządzenie Rady Ministrów z dnia 14 września 1922 roku w przedmiocie organizacji sądownictwa na Spiszu i Orawie i rozciągnięcia na ten obszar mocy obowiązującej niektórych ustaw i rozporządzeń (Dz.U. z 1922 r. Nr 90, poz. 833).

Rozporządzenie Prezydenta Rzeczypospolitej z dnia 6 lutego 1928 roku Prawo o ustroju sądów powszechnych (Dz.U. z 1928 r. Nr 12, poz. 93).

Rozporządzenie Prezydenta Rzeczypospolitej z dnia 19 marca 1928 roku Kodeks postępowania karnego (Dz.U. z 1928 r. Nr 33, poz. 313).

Rozporządzenie Prezydenta Rzeczypospolitej z dnia 19 marca 1928 roku Przepisy wprowadzające kodeks postępowania karnego (Dz.U. z 1928 r. Nr 33, poz. 314).

Rozporządzenie Prezydenta Rzeczypospolitej z dnia 23 sierpnia 1932 roku zmieniające niektóre przepisy postępowania karnego (Dz.U. z 1932 r. Nr 73, poz. 662).

Prawo 328, 2019

(C) for this edition by CNS 
Ustawa z dnia 3 czerwca 1919 roku o komisji kodyfikacyjnej (Dziennik Praw Państwa Polskiego z 1919 r. Nr 44, poz. 315).

Ustawa z dnia 21 stycznia 1932 roku zmieniająca niektóre przepisy postępowania karnego (Dz.U. z 1932 r. Nr 10, poz. 60).

Ustawa z dnia 9 kwietnia 1938 roku o zniesieniu instytucji sądów przysięgłych i sędziów pokoju (Dz.U. z 1938 r. Nr 24, poz. 213).

Ustawa z dnia 27 kwietnia 1949 roku o zmianie prawa o ustroju sądów powszechnych (Dz.U. z 1949 r. Nr 32, poz. 237).

Ustawa z dnia 27 kwietnia 1949 roku o zmianie przepisów postępowania karnego (Dz.U. z 1949 r. $\mathrm{Nr} 32$, poz. 238).

Ustawa z dnia 20 lipca 1950 roku o Prokuraturze Rzeczypospolitej Polskiej (Dz.U. z 1950 r. Nr 38, poz. 346).

Ustawa z dnia 20 lipca 1950 roku o zmianie prawa o ustroju sądów powszechnych (Dz.U. z 1950 r. $\mathrm{Nr} 38$, poz. 347).

Ustawa z dnia 20 lipca 1950 roku o zmianie przepisów postępowania karnego (Dz.U. z 1950 r. Nr 38, poz. 348).

Ustawa z dnia 19 kwietnia 1969 roku Kodeks postępowania karnego (Dz.U. z 1969 r. Nr 38, poz. 96).

\section{Projekty aktów prawnych}

Projekt ustawy postępowania karnego, przyjęty przez Komisję Kodyfikacyjna Rzeczypospolitej Polskiej w dniu 26 kwietnia 1926 r. z uzasadnieniem i tablica porównawczą, [w:] Komisja Kodyfikacyjna Rzeczypospolitej Polskiej, Sekcja Postepowania Karnego, t. 1, z. 1, Lwów 1926.

Projekt ustawy postępowania karnego, przyjęty w II czytaniu przez Sekcję Postępowania Karnego Komisji Kodyfikacyjnej Rzeczypospolitej Polskiej, Warszawa 1924.

\section{Literatura}

Barcikowski W., Ważniejsze zagadnienia ustawodawcze, „Demokratyczny Przegląd Prawniczy” 1946, nr 2.

Bzowski K., Dwie czy trzy instancje w postępowaniu karnym, „Głos Sądownictwa” 1936, nr 5.

Bzowski K., Jeszcze o liczbie instancji w postepowaniu karnym, „Gazeta Sądowa Warszawska” 1936, $\mathrm{nr} 42$.

Cyprian T., Rewizja nadzwyczajna, „Demokratyczny Przegląd Prawniczy” 1949, nr 6-7.

Daszkiewicz W, Paluszyńska-Daszkiewicz K., Proces karny i materialne prawo karne w Polsce w latach 1918-1939, Torun 1965,

Grodziski S., Komisja Kodyfikacyjna Rzeczypospolitej Polskiej, „Czasopismo Prawno-Historyczne” 33, 1981, nr 1.

Górnicki L., Prawo cywilne w pracach Komisji Kodyfikacyjnej Rzeczypospolitej Polskiej w latach 1919-1939, Wrocław 2000.

Historia państwa i prawa Polski 1918-1939, red. F. Ryszka, cz. 2, Warszawa 1968.

Kallas M., Lityński A., Historia ustroju i prawa Polski Ludowej, Warszawa 2000.

Komisja Kodyfikacyjna Rzeczypospolitej Polskiej, Dziat Ogólny, t. 1, z. 3, Warszawa 1921.

Komisja Kodyfikacyjna Rzeczypospolitej Polskiej, Podkomisja ustroju sądownictwa, t. 1, Lwów 1925.

Konferencja w sprawie reformy ustroju i postępowania sq̨dowego, „Demokratyczny Przegląd Prawniczy" 1947, nr 4.

Koredczuk J., Wpływ nurtu socjologicznego na kształt polskiego prawa karnego procesowego w okresie międzywojennym, Wrocław 2007.

Lityński A., O prawie i sądach początków Polski Ludowej, Białystok 1999.

Prawo 328, 2019

(C) for this edition by CNS 
Lityński A., Wydziat karny Komisji Kodyfikacyjnej II Rzeczypospolitej. Dzieje prac nad częścia ogólna kodeksu karnego, Katowice 1991.

Mohyluk M., Porzadkowanie prawa w II Rzeczypospolitej. Komisja Kodyfikacyjna i Rada Prawnicza, „Czasopismo Prawno-Historyczne” 51, 1999, nr 1-2.

Muszkat M., O reformę ustroju sądownictwa i prokuratury, „Demokratyczny Przegląd Prawniczy” $1945, \mathrm{nr} 2$.

Papierkowski Z., W sprawie reformy wymiaru sprawiedliwości, „Demokratyczny Przegląd Prawniczy" 1947, nr 9.

Pasek A., Dekret PKWN z 31 sierpnia 1944 r. (sierpniówka). Próba analizy historycznoprawnej, „Czasopismo Prawno-Historyczne" 51, 1999, nr 1-2.

Pasek A., Odstępstwo od narodowości w polskim prawie karnym lat 1944-1945, „Prawo” 261, 1998.

Pasek A., Przestępstwa okupacyjne w polskim prawie karnym z lat 1944-1956, „Prawo” 325, 2002.

Pasek A., Uwagi o źródłach polskiego prawa karnego materialnego z lat 1944-1950, [w:] W kręgu dziejów prawa karnego, red. P. Jurek, Wrocław 1999.

Pasek A., Z organizacyjnych zagadnień kodyfikacji prawa karnego w Drugiej Rzeczypospolitej, „Prawo" 288, 2004.

Pasek A., Zasada udziału czynnika społecznego w procesie karnym w początkach Polski Ludowej, [w:] Zasady prawne w dziejach prawa publicznego i prywatnego, red. M. Podkowski, Wrocław 2015.

Płaza S., Kodyfikacja prawa w Polsce międzywojennej, „Czasopismo Prawno-Historyczne” 57, 2005, nr 1.

Protokót I posiedzenia Wydziału Karnego, [w:] Komisja Kodyfikacyjna Rzeczypospolitej Polskiej, Wydziat Karny. Prawo Materialne, t. 1, z. 1, Warszawa 1921.

Protokół II posiedzenia Wydziału Karnego, [w:] Komisja Kodyfikacyjna Rzeczypospolitej Polskiej, Wydział Karny. Prawo Materialne, t. 1, z. 1, Warszawa 1921.

Radwański Z., Ksztattowanie się polskiego systemu prawnego w pierwszych latach II Rzeczypospolitej, „Czasopismo Prawno-Historyczne” 21, 1969, nr 1.

Sawicki J., Maślanko M., Kontrola rewizyjna, „Demokratyczny Przegląd Prawniczy” 1949, nr 6-7.

Siewierski M., O reformę wymiaru sprawiedliwości w dziedzinie karnej, „Demokratyczny Przegląd Prawniczy" 1946, nr 2.

Świątkowski H., Doniosłe reformy wymiaru sprawiedliwości, „Demokratyczny Przegląd Prawniczy” 1950, nr 8-9.

Świątkowski H., Prace i zamierzenia Ministerstwa Sprawiedliwości, „Demokratyczny Przegląd Prawniczy" 1946, nr 1.

Świątkowski H., Reformy w dziedzinie prawa karnego, „Demokratyczny Przegląd Prawniczy” 1949, nr 4.

Uzasadnienie rzadowe do projektu zmiany kodeksu postępowania karnego, „Demokratyczny Przegląd Prawniczy" 1949, nr 6-7.

Zebranie organizacyjne Komisji Kodyfikacji Prawa Karnego, „Demokratyczny Przegląd Prawniczy” 1947, nr 10.

\section{Evolution of the right of appeal in the Polish Code of Criminal Procedure of 1928}

\section{Summary}

The study is devoted to the evolution of the right of appeal in the Polish Code of Criminal Procedure of 1928. The author discusses the most important stages of the work on the draft code. He demonstrates that the Polish Code of Criminal Procedure of 1928 was characterised by the principle of three-level proceedings (first instance, appeal and cassation), which was an important element of 
procedural guarantees. It should be noted that the proposal, repeatedly presented in the literature, to abolish appeal and transform three-level proceedings into two-level proceedings was not put into practice in the inter-war period.

After the end of the Second World War the legislator in communist Poland did keep the 1928 Code of Criminal Procedure in force, but new legislative acts were issued, constructing a special kind of two-level proceedings, which combined elements of appeal and cassation. Then, one of the elements of a major amendment to the Code of Criminal Procedure in 1949-1950 was the replacement of three-level proceedings including appeal and cassation, with two-level revision proceedings.

Keywords: Codification Commission, draft law, criminal proceedings, instance

\section{Die Evolution des Grundsatzes des Instanzenzuges in der polnischen Strafprozessordnung aus dem Jahre 1928}

\section{Zusammenfassung}

Die Bearbeitung wurde der Entwicklung des Grundsatzes des Instanzenzuges in der polnischen Strafprozessordnung aus dem Jahre 1928 gewidmet. Besprochen wurden die wichtigsten Etappen der Arbeit an dem Entwurf des Gesetzbuches. Es wurde bewiesen, dass der Grundsatz des dreiinstanzlichen Verfahrens (Berufung und Kassation), der ein wichtiges Element der Verfahrensgarantien darstelle, für die polnische Strafprozessordnung aus dem Jahre 1928 charakteristisch war.

Der Gesetzgeber Volkspolens bewahrte zwar nach dem Ende des Zweiten Weltkrieges die Gesetzeskraft der Strafprozessordnung aus dem Jahre 1928, aber gleichzeitig gab er neue Rechtsakte heraus, in welchen er ein zweiinstanzliches Verfahren spezifischen Charakters konstruierte, das Elemente der Berufung und Kassation verband. Später war der völlige Verzicht auf das dreiinstanzliche Berufungs-Kassations-Verfahren ein der Elemente der grundsätzlichen Novellierung der Strafprozessordnung in den Jahren 1949-1950 zugunsten des zweiinstantionellen Revisionsverfahrens.

Schlüsselworte: Kodifikationskommission, Gesetzentwurf, Strafverfahren, Instanz 